\title{
GLOBAL FINANCIAL MARKET TURBULENCE: FACTORS AND RISKS ${ }^{1}$
}

\author{
A.Kiyutsevskaya, P.Trunin
}

In the last few months, the global economy has been faced with growing risks primarily emanating from the state of the world's two largest economies and their policies. One of the main factors behind the current turbulence in global financial markets is the destabilizing expectation that the US Federal Reserve is going to toughen its policy stance. The ongoing decline in unemployment and the steady rebound in business activity have created preconditions for a rise in the US Federal Reserve's key interest rate. As far as the developing economies are concerned, the most likely result of this decision will be an increase in the rate of capital outflow and a new wave of currency depreciations. The second and maybe even more important factor is China's continuing deceleration in economic growth, the collapse of its stock market and the unexpected devaluation of the Yuan.

In 2012-15, global economic development was characterized by the steadily increasing rates of economic growth in a number of developed economies (including the USA and some European countries) and a notable decline in manufacturing in the developing countries. The gap in economic growth rates between the developed and developing economies decreased from its pos-crisis maximum of 4.5 p.p. in 2011 to 2.8 p.p. in 2014. According to the April 2015 estimates of the IMF, by the end of 2015 this gap may further decrease to 1.9 p.p. At the same time, the intensification of negative trends in China's economy and the continuing economic slump in Brazil and Russia are creating preconditions for an even faster shrinkage of the gap in economic growth rates between the developed and developing economies (Fig. 1).

It should be noted that both the ongoing slowdown of China's economy and the collapse of its stock market this summer have been largely caused by the active market stimulus policy pursued by the Chinese authorities in the post-crisis period. As a matter of fact, the first signal about the emergence of alarming trends in the Chinese economy was the rapid rise in real estate prices. In spring 2013, China's government began to make efforts at cooling down the real estate market. As a result, that market notably stagnated which, in its turn, caused the structure of investment portfolios to change, thus creating a bubble on the stock market. It took the Shanghai Composite index (China's key stock index) just slightly more than two years (from 1 April 2013 through 12 June 2015) to grow more than twofold, reaching a high 5,166 on 12 June 2015. It should be noted that during the first half-year 2015 alone, it rose by $59.7 \%$ (Fig. 2 ).

1 This paper was originally published in Monitoring of Russia's Economic Outlook. Trends and Challenges of Socio-economic Development. No 13. October 2015.

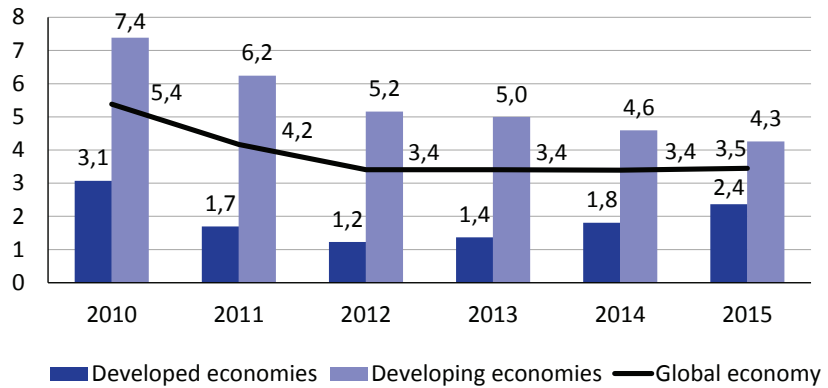

Sources: International Monetary Fund, World Economic Outlook, April 2015, www.imf.org

Fig. 1. Growth Rate of Global GDP, \%

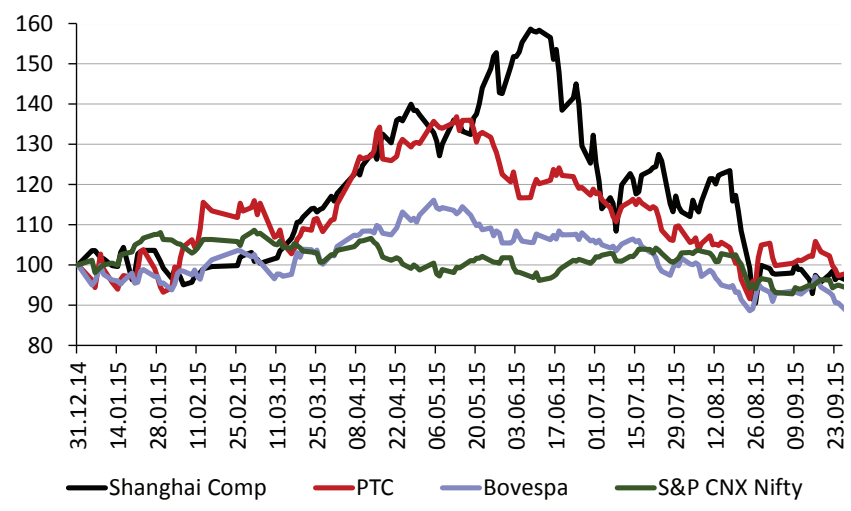

Fig. 2. Behavior of the Key Stock Indices of Developing Economies (31 December 2014 = 100\%).

The growing attractiveness of the developing countries' highly risky financial assets was determined, among other things, by the persistence of extremely low interest rates in most of the developed economies, and most importantly, in the USA ${ }^{2}$. Thus, in May 2015, despite the intensification of economic slump in Brazil (Fig. 3), the Bovespa Index, the flagship index of the

2 B. Zamaraev, A. Kiyutsevskaya, Rossiiskaya ekonomika v kontekste mirovykh trendov [The Russian Economy in the Context of Global Trends] // Voprosy Ekonomiki [Issues of Economics]. No 2, 2015, pp. 5-21. 


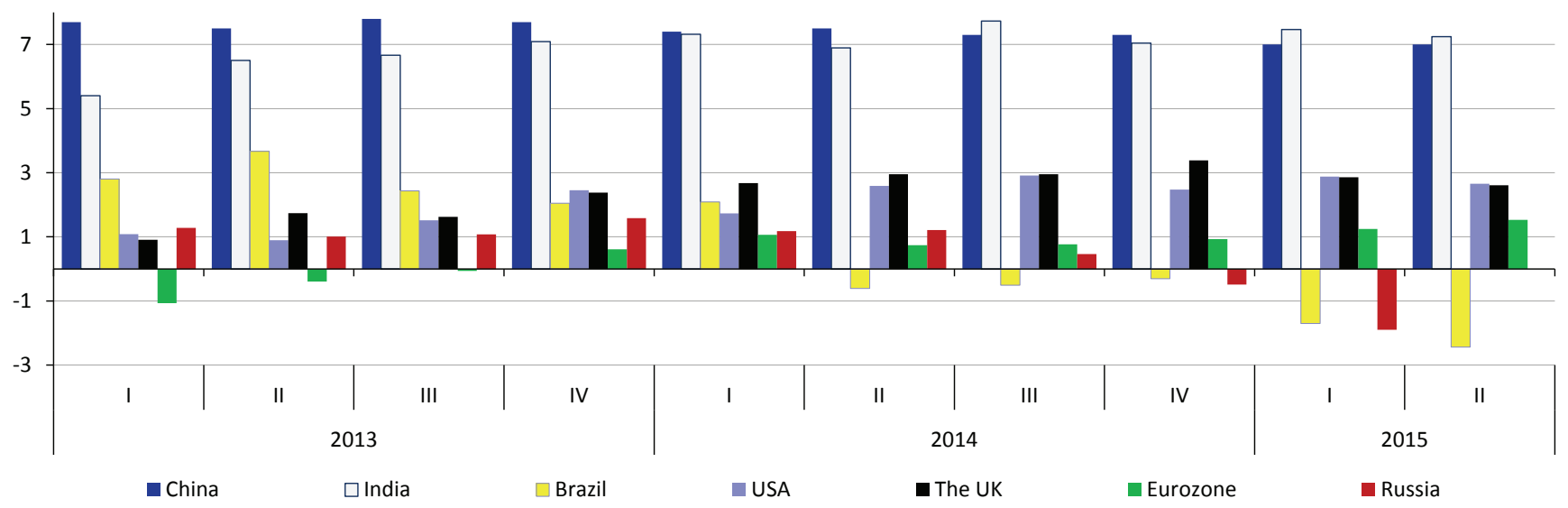

Sources: International Monetary Fund, International Financial Statistics, April 2015, www.imf.org

Fig. 3. GDP Growth Rate Relative to Corresponding Period of Previous Year, as \%

Brazilian stock exchange, rose above 58,000 , having gained more than $16 \%$ since the beginning of the year.

However, the improvement of the economic situation in the USA, as well as the official declarations on the part of the US Federal Reserve' head about their readiness to begin to raise the interest rates already over the course of this year triggered the downward movement of the ker stock exchange indices in the developing countries, as well as a more rapid outflow and depreciation of their national currencies ${ }^{1}$. Among the biggest developing economies, the steepest downfall in 2015 was demonstrated by the Brazilian real, whose nominal exchange rate against major world currencies had lost 33.2\% by December 2014 (Fig. $4^{2}$ ).

Thus, while the developed countries are faced with persistent deflation risks, the developing ones are experiencing a rise in inflation risks. The latter problem is most acute in Brazil, where consumer prices rose by $9.5 \%$ on the same period of last year, while the inflation target set by the Central Bank of Brazil is $4.5 \%$ with the tolerance band of 2 percentage points either way. As a result, over the course of the current year, the Central Bank of Brazil has raised the key interest rate to $14.25 \%$ per annum, while in late December 2014 it had amounted to $11.75 \%$. The South African Reserve Bank also raised its key interest rate twice over the course of 2015. At the same time, some developing economies have not toughened their monetary policies. Thus, in continuation of its policy of monetary easing, the Central Bank of the Republic of Turkey kept on softening its stance by reducing the key interest

1 The factors responsible for the Russian ruble's depceciation are discussed in detail in: A. Bozhechkova, P. Trunin. Infliatsiia uskoriaetsia, kurs rublia po-prezhnemu zavisit ot tsen na energonositely [Inflation Is accelerating, the Ruble's exchange Rate, As Before, Depends on Prices of Energy Carriers]. Monitoring of Russia's Economic Outlook. Trends and Challenges of Socio-economic Development. No 12 (September) 2015.

2 The index's upward movement indicates its strengthening against the US dollar.

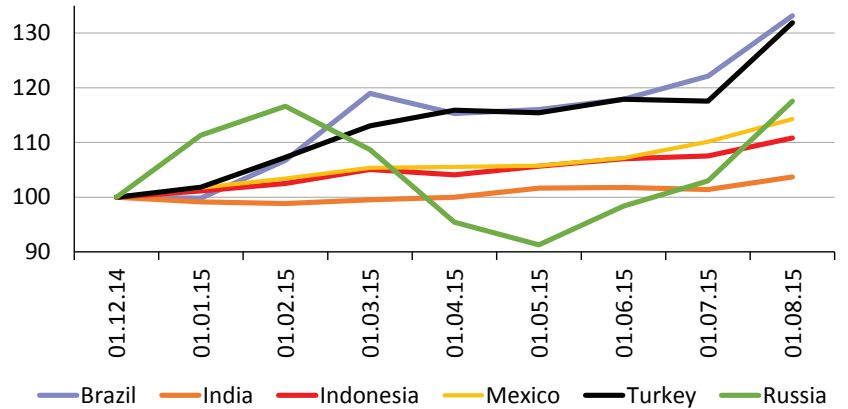

Fig. 4. The Movement of the US Dollar's Exchange Rate against the National Currencies of Developing Countries

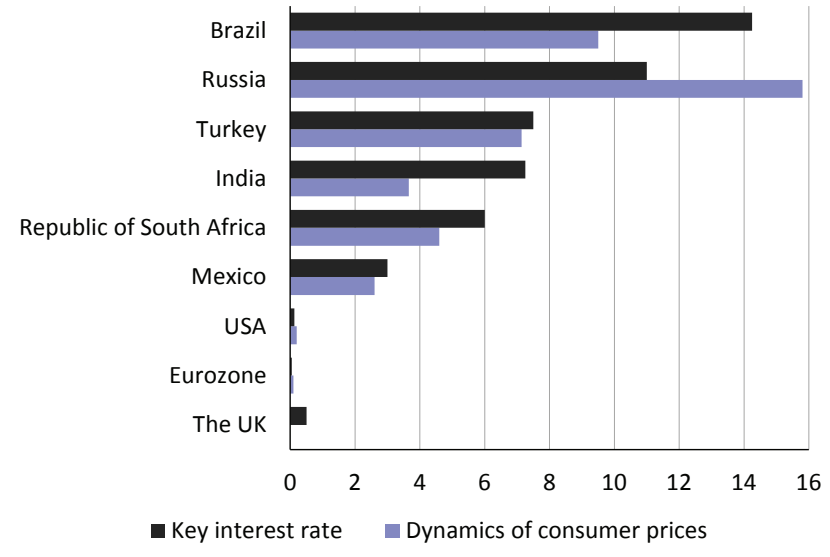

Fig 5. Growth Rate of Consumer Prices on the Corresponding Period of the Previous Year and the Key Interest Rates of CBs as of the End of August 2015, \%

rate from $8.25 \%$ per annum at the beginning of 2015 to $7.5 \%$ per annum (Fig. 5).

The devaluation of the yuan delivered a heavy shock to global financial markets. The initial decision of the Chinese authorities, of 11 August 2015, that the yuan should be devalued by $1.9 \%$ was considered a 'one-time correction'. However on $12^{\text {th }}$ and $13^{\text {th }}$ August, the yuan was once again devalued - by $1.6 \%$ and $1.1 \%$, respectively. On 25 August, the USD to CNY exchange rate rose to $6.413 \mathrm{CNY}$, and then began to decline (Fig. 6). 
The devaluation of the yuan was caused by a very sharp decline in Chinese exports and the resulting drop of capital inflows into China. As a result, the Central Bank of China was forced the People's Bank of China to carry out a number of massive interventions in the foreign exchange market, thus depleting China's international reserves, over the course of the first half-year 2015 alone, by more than $\$ 97.6 \mathrm{bn}$. The devaluation of the yuan triggered panic on the global financial market and caused a rapid drop in the key stock exchange indices and a sharp rise in their volatility. Thus, since 11 August 2015, the one-month volatility of Nasdaq (USA), CAC (France), and DAX (Germany) have risen to $3.2 \%, 4.7 \%$ and $4.5 \%$ respectively. For reference: in July-August 2015, their one-month volatility did not exceed $1 \%, 1.5 \%$ and $1.6 \%$ respectively (Fig. 7 ).

The negative processes in China's economy and the expected toughening of the FRS's stance caused a notable decline in the prices of raw materials. Thus, during the July-September period, the average monthly price of Brent crude oil dropped by $14.9 \%$, while that of copper - by $5.7 \%$. At the same time, according to the Food and Agriculture Organization of the United Nations (FAO), world food commodities prices (for cereals, meat products, vegetable oils and sugar) dwindled, in August 2015 alone, by $5.2 \%$, which represented their fastest decline since December 2008.

On the whole, the current world economic situation is heavily influenced by both the economic situation in China and the expectations concerning the forthcoming decisions of the US Federal Reserve. At the same time, the Federal Reserve's policy will certainly take into consideration the situation in China's economy. If it deteriorates too drastically, the US Federal Reserve will be able to slow-down the transition to higher interest rates, which is expected to take place as early

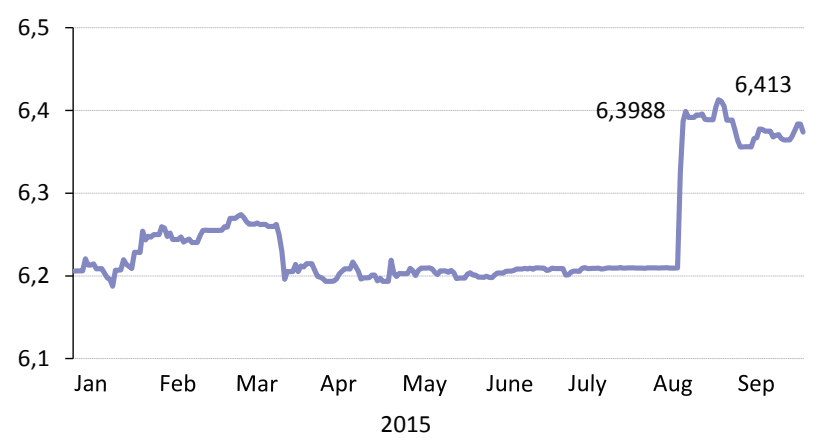

Sources: http://www.forexpros.ru/currencies/usd-cny-historical-data

Fig. 6. Behavior of the USD-CNY Exchange Rate in 2015

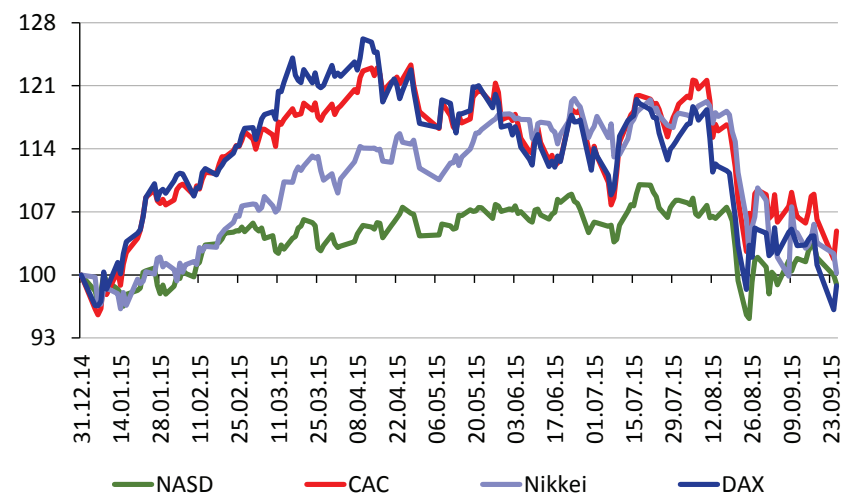

Source: www.finam.ru

Fig. 7. Behavior of the Key Stock Exchange Indices of Developed Economies

as before the end of this year. If the situation in the Chinese economy remains tolerable, the US Federal Reserve will begin raising interest rates. As far as the developing economies are concerned, the most likely result of this decision will be an increase in the rate of capital outflow and a new wave of currency depreciations. 